\title{
JOBBAN TELJESÍT
}

\section{Centralizáció és minőség}

\author{
Bordás Péter-Bartha Ildikó-Horváth M. Tamás \\ (MTA-DE Közszolgáltatási Kutatócsoport, DE ÁJK)
}

A tanulmány beérkezett: 2019. szeptember 24. - opponálás: 2019. október 1. 2019. november 5. - véglegesítve: 2019. november 29.

\section{ÖSSZEFOGLALÓ}

Kákai László és Vető Balázs a Politikatudományi Szemle hasábjain a hazai önkormányzati változásokat a centralizációval ellenpontozva vizsgálta, és arra a következtetésre jutott, hogy a lakossági vélemények alapján központi szervezéssel az ellátások nem kerültek jobb kezekbe. Jelen tanulmány szerint a helyben hagyott feladatkörök tekintetében sem látszik, hogy az őket is érintő központosító pénzügyi szabályozás érzékelhető pozitív változást hozott volna. A fogyasztói elégedettség mutatói nemzetközi összehasonlításban sem kedvezőek. A körülmény, miszerint nem a közszolgáltatások igénybe vevői szempontja állt előtérben, azonban nem jelenti azt, hogy az átalakítások céltalanok lettek volna, és a helyben nyújtott közfeladatellátás fejleményeit csak sodródással jellemezhetnénk. Ezt az állításunkat nemcsak empirikus elégedettségi összehasonlító és longitudinális vizsgálatok elemzésével, hanem megállapításaink érvényességi körének pontosabb lehatárolásával is igyekszünk alátámasztani.

\footnotetext{
Kulcsszavak: helyi önkormányzatok @ centralizáció — feladat-

finanszírozás - közszolgáltatás-

szervezés — hatékonyság vs. társadalmi eredményesség
}

- Eddig is múködött, mi változik?

- Semmi az égvilágon.

- Akkor mitól lesz jobb?

- Hatékonyabb lesz.

(Kormányzati átalakitásról szóló diskurzus egy

felsôvezetôi fórumon)

Kákai László és Vető Balázs a magyar helyi önkormányzati rendszer átalakításáról írt értő tanulmányt (Kákai-Vető, 2019) a Politikatudományi Szemle 
2019. évi 1. számában, a központosítást a decentralizációhoz képest kutatva. Az elemzéssel alapvetően egyetértve ahhoz az alábbiakban azzal kívánunk hozzájárulni, hogy a centralizáció „önértékét” összehasonlításban igyekszünk vizsgálni. Míg az említett tanulmány a központosítás értékelését a decentralizációhoz viszonyítva vizsgálja, itt magát a teljesítményt próbáljuk összehasonlítható formában kifejezni, tekintet nélkül az alapvető területi szervezési elvben történő értékválasztásra.

Szak- (jelen esetben pénzügy-) politikai értelemben ennek a nézőpontnak a haszna az, hogy a közfeladat-ellátást magát és nem annak ellátásmódját minősítjük. Elvileg és gyakorlatilag ugyanis a központosítás lehet eredményesebb, mint a decentralizált megoldás alkalmazása. Politikai intézményi értelemben ezzel a megközelítéssel a centralizáció saját múködési racionalitásairól tudunk meg többet. Eredményeink egyébként megerősítik a szerzőpáros állításait kiegészítve annyival, hogy az önállóan értelmezett központi kormányzati felelősségvállalás, illetve finanszírozás így nem amolyan "fekete dobozként" tûnik fel, hanem az éppen adott múködési és ekként mindenkor mérhető, ugyanakkor persze változó realitásként. Politológiai értelemben a témához való hozzáadott érték részünkről jelen esetben ez.

A legtöbb európai országban az állami területi szintek közötti feladatmegosztás alapja a pénzügyi forrásszabályozási rendszer, ami megegyezik a korábban nálunk is alkalmazott gyakorlattal. Tükröződik ez a szisztéma mindenekelőtt a finanszírozás jellegében, mikor is a helyben képződött ún. saját és megosztott bevételeknek nagyobb a szerepe és az aránya a helyi közfeladatok finanszírozásában. A kiadásszabályozás ezzel szemben az elismert feladatok kiadásait központilag tervezi és fedezi.

Hipotézisünk az, hogy ez, a nálunk megvalósított és a centralizáció részévé tett ún. feladatfinanszírozásra épülő támogatási rendszer csak kevésbé lehet közösségi értelemben eredményes, azaz értelmezésünkben fogyasztóbarát. A feladatalapú finanszírozás a finanszírozott feladatot költségvetési kiadási tervezési előirányzatokkal határozza meg, a tényleges teljesítmény értékelését ezért csak „visszamérésre" használhatja. A fogyasztói érdekeltség összetettebb szempontjainak, mint amilyen a participáció, merev központosítás mellett történő figyelmen kívül hagyása végeredményben a közösségi elégedettség gyengüléséhez vezet. Mindazonáltal ez a körülmény nem egyszerúen a decentralizáció javára szól, hanem mértéke révén a centralizmus adott megvalósítási formáját is minősíti. (A participáció példájánál maradva, annak nemcsak területi önkormányzati megoldásai lehetségesek, de ha azok is hiányoznak, akkor ennek révén is keletkezik társadalmi deficit.)

Az egyes feladatok ellátásával való elégedettséget tehát érthetjük így is, és akkor nem egyszerúen a megelőző decentralizált modellhez képest, hanem a múködés rendszerének belátható folyományára is következtéseink adódnak. 


\section{MÓDSZER}

A kutatás alapjául mindenekelőtt két másik kutatás által, a Belügyminisztérium (BM) számára végzett reprezentatív megkérdezés szolgált, melyek eredményeit a projektzáró összefoglalók elkészítése után, újbóli elsődleges feldolgozásra kutatócsoportunk rendelkezésére bocsátottak. ${ }^{1}$ Mellettük a nemzetközi összehasonlító elemzéshez az Európai Bizottság Regionális és Várospolitikai Főigazgatóságának Flash Eurobarometer - Quality of Life in European Cities címú felmérése keretében készített, nyilvánosan elérhető adatokat (a továbbiakban: EC, 2010; EC, 2013; EC, 2016) dolgoztuk fel.

A BM egyik, a TÁRKI által végzett felmérése lakossági lekérdezés volt, melynek keretében 2017 tavaszán összesen 4004 db érvényes kitöltött kérdőív érkezett vissza (a továbbiakban: lakossági felmérés, 2017). A kérdőívezés során utólagos mintavételezéssel került biztosításra, hogy a felmérésben résztvevő települések megfelelően reprezentálják az összes releváns magyarországi településkategóriát. A relatívan magas mintavétel alkalmas volt arra, hogy egyes településkategóriákra, illetve megyei szinten is reprezentatívak legyenek az adatok (KJ 1, 2018: 29-30.). A megkérdezés egyebek között 25 helyi közszolgáltatás minőségi paramétereire és a hozzájuk kapcsolódó elégedettségre kérdezett rá.

A BM másik felmérése a polgármesterek és jegyzők körében, 2018 tavaszán elvégzett lekérdezés volt (a továbbiakban: önkormányzati felmérés, 2018). A kérdőívet elektronikus formában az összes magyarországi önkormányzatnak kiküldték, melyet több emlékeztető felhívás követett. A válaszokat 1026 önkormányzat küldte vissza. A reprezentativitást a településkategóriákra szólóan tesztelték. Nem vizsgáltuk mind a 25 közszolgáltatást (KJ 2, 2018: 25.). Csak azokat a közszolgáltatásokat emeltük ki, amelyben a megkérdezett települések minden bizonnyal érintettek, így például az óvodai és bölcsődei nevelésben, a szociális étkeztetésben, a közterek minőségében, a hatósági munka hatékonyságában.

A nemzetközi összehasonlításhoz használt „Quality of Life in European Cities" felmérése keretében mindösszesen 79 európai városban készült felmérés. A lekérdezés az érintett országok fővárosaira, valamint a nagyobb országok további - egy és hat közötti számú - városára terjed ki.

Mivel a mi kérdésünk nem az, hogy a decentralizált megoldáshoz képest milyen a centralizáció, hanem az, hogy a centralizált döntéshozatali és finanszírozási rendszerben megmaradó helyi feladatellátás jobb vagy rosszabb lett-e, ezért kizárólag olyan funkciókat tettünk vizsgálat és összehasonlítás tárgyává, amelyek ellátása Magyarországon önkormányzati hatáskörben volt és még jelenleg is abban maradt (vö. Kákai-Vető, 2019: 33.). A közoktatást vagy a kórházi ellátást például azért nem, mert ezek már kikerültek a helyi rendelkezés köréből. 


\section{ELMÉLETI KERETEK ÉS PROBLÉMAKÖRNYEZET}

A pénzügyi föderalizmus több mint fél évszázada gyarapodó elmélete nagyban hozzájárul a centralizáció-decentralizáció folyamatának tudományos megértéséhez (Musgrave, 1956). A pénzügyi decentralizáció többek között azt a jelenséget írja le, hogy a kormányzati egységek gazdasági értelemben egymással interaktív viszonyban vannak, mely keretében különböző közszolgáltatási preferenciákat fogalmaznak meg, és ezzel összefüggésben álló adószinteket állítanak be. Ch. Tiebout mobilitási hipotézise szerint az emberek ideális esetben választanak a különböző kormányzatok által fölkínált szolgáltatások és a helyi adóteher összefüggésében, hol tudják kedvezőbben kielégíteni közösségi szükségleteiket (Tiebout, 1956). A modell szerint odaköltöznek, ahol a feltételek összességében nekik kedvezőbbek, azaz a „lábukkal szavaznak" (Horváth $M, 2002: 41-45$.). Ez azonban természetesen nem mindig és minden esetben igaz, mert az abszolút és relatív tranzakciós költségek nagyon magasak is lehetnek.

Ehhez szorosan kapcsolódik Oates elméletének alapgondolata, amely szerint léteznek helyi szinten biztosított közjavak, közszolgáltatások, amelyek esetében a kereslet területenként eltérő (Oates, 1972). A helyi közjavak olyan közjavak, amelyek előnyeit az adott ország népességéből csak egy meghatározott területén élők élvezhetik (Hydman, 2011: 712.). A gyakorlatban majdnem minden olyan közszolgáltatást ide sorolhatunk, amelynek előállítása helyi szinthez kötött, s közjószág lévén senki sem zárható ki annak fogyasztásából, így példaként említhetô egy helyi közpark, játszótér, egyes egészségügyi ellátások, de akár egy idősek otthona is. Ugyanakkor az ebből adódó túlcsordulási hatás (spillover effect) a helyi önkormányzatok oldalán problémát jelenthet, hisz magas kiadásokkal kell megbirkózniuk, miközben lehet, hogy az igénybevevők széles köre nem az adott településen fizet adót (Bailey, 1999: 9.). Sőt az is előfordulhat, hogy saját lakosai kiszorulhatnak az adott szolgáltatásból. Tipikus jelenség ez az ún. központi funkciókat betöltő városokban, amely a magyar önkormányzati, feladatellátási rendszerben is jelen van. Fontos kérdés tehát, hogy a szabályozás hogyan tudja kezelni ezen közfeladat-ellátási, finanszírozási kérdéseket úgy, hogy a lakosság közszolgáltatásokkal való elégedettsége ne romoljon.

A decentralizáció sajátossága, hogy a feladat- és hatáskörök decentralizációjával együtt kell járnia a források telepítésének is, mivel pénzügyi önállóság nélkül nem beszélhetünk döntési autonómiáról. A helyi kormányzati egységek bevételi szerkezete változatos képet mutat térben és időben. Egy biztos, hogy saját bevételek és kormányzati transzferek minden fejlett, többszintû pénzügyi kormányzás elvén múködő államban megtalálhatóak, s az arányuk alapján különböző modellekbe sorolhatók (1. ábra). 
1. ábra. Önkormányzati bevételi források megoszlása a teljes bevétel százalékában, egyes OECD országokban, 2016

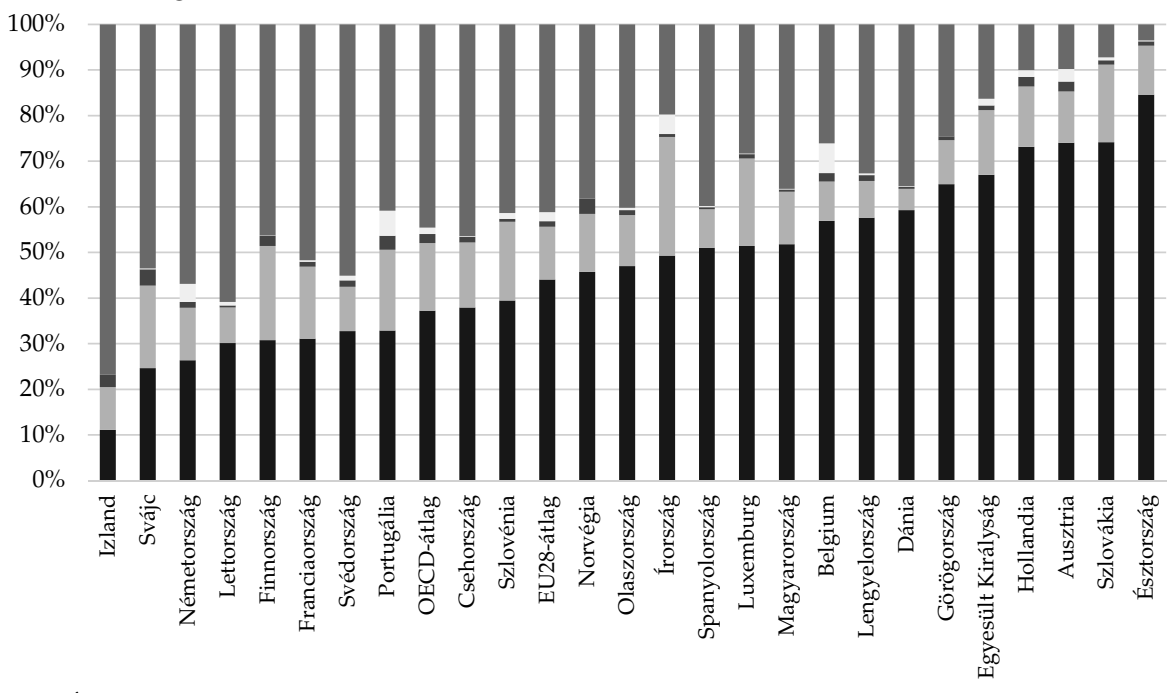

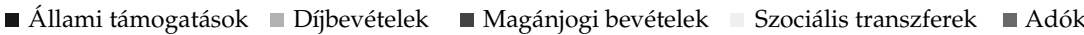

Forrás: OECD, 2016 adatai alapján, a szerzők

A kategóriák tartalma ugyanakkor sokkal változatosabb képet mutat az adott ország történelmi hagyományainak, gazdasági berendezkedésének, vagy épp a kormányzati céloknak megfelelően. A forrásszerkezetben a saját bevételek (helyi adók, megosztott bevételek, használati díjak) képezhetik a decentralizált feladatellátás alapját, s az eltérő mérettel és kapacitással rendelkező egyes önkormányzatok közötti különbségeket kiegyenlítő kormányzati transzferekkel kell kezelni. A delegált feladatok ellátását pedig központi kormányzati támogatások útján célszerü finanszírozni (Martinez-Vazquez-Sepulveda, 2012: 11.).

Az is látható ugyanakkor, hogy mára pusztán a saját bevételek vagy épp a kormányzati transzferek aránya önmagában nem lehet a decentralizáció mércéje vagy a centralizációvá minősítés alapja. A nagyobb arányú központi forrás elosztása is lehet szabályozott és átlátható, illetve viszonylag sok saját bevétel is lehet célszerûtlen, ha a felhasználás nem ellenőrzött és pazarló. Az európai önkormányzati pénzügyi rendszerek nagyon változatos képet mutatnak, a globális hatásoknak köszönhetően egymással kölcsönhatásban fejlődnek (HortaFornes, 2015: 29.). Az önkormányzati modellekben egyre inkább eltérő a fiskális decentralizáció mértéke is, mely szintén folyamatos változás alatt áll (Péteri, 2016: 22). 
A Kákai-Vető-féle, 2019-es tanulmányt kiegészítve rögzíthetjük, hogy a helyi önkormányzatok hazai centralizációjának két dimenziója van. Egyrészt a nagy költségvetési volumenü feladatok (közoktatás, középfokú egészségügyi és szociális ellátás - melynek pénzügyi következményeit a 2. melléklet szemlélteti) központosítása, másrészt a megmaradó helyi önkormányzati pénzügyi szabályozás döntéseinek centralizálása a települési szintű önálló mérlegelés körének jelentős korlátozása útján. Mivel egy közszolgáltatási feladat ellátásának központi megszervezése még nem feltétlenül hatékonytalan vagy kevésbé hatékony, az átalakítás teljesítményét, mint említettük, mi az önkormányzatoknál megmaradó feladatok ellátási színvonalának viszonyításon alapuló értékelése útján látjuk célszerüen mérhetőnek.

Szükséges ehhez először is a régi és az új szabályozási környezet különbségének vázlatos áttekintése. A Magyarország helyi önkormányzatairól szóló törvény pénzügyi csodafegyvere, a feladatfinanszírozás 2013 óta szolgál. Az akkor új finanszírozási megoldás a korábbiakhoz képest más logikát ígért. A rendszerváltástól múködő forrásszabályozási megoldást elavultnak ítélték, s annak korrigálása helyett kiadásorientált rendszert vezettek be, amelyet feladatfinanszírozásnak neveztek. A hatálybalépés óta eltelt időszak számos tapasztalattal szolgál, hiszen a kormányzati szintek közötti pénzügyi kapcsolatok és az azt meghatározó finanszírozási technikák amúgy is folyamatos „mozgásban" vannak. Számos finanszírozási változás lezajlott, így módosultak a támogatási jogcímek, az átengedett és megosztott bevételek köre, illetve megkezdődött az adósságkonszolidáció is.

E vízválasztó időszakban a decentralizáció ellen felsorakoztatott érvek rendkívül előtérbe kerültek, továbbá a méretgazdaságosság, a hatékonyság, elszámoltathatóság elveit hangoztatva a centralizált feladatellátás kapott nagyobb szerepet. Ennek megfelelően 2013-tól a központi költségvetési támogatások volumenben csökkentek, tartalmukat illetően pedig a normatív támogatások nagy része kötött felhasználásúvá vált. Az új támogatási filozófia lényege a források szabályozása helyett a költségalapú feladatfinanszírozás lett, beleértve a fejlesztési beruházásokat is. ${ }^{2}$ További érzékletes változás, hogy az összes támogatáson belül kevésbé differenciáltak a támogatási formák. A helyi önkormányzatok kiegészítő támogatása a rendszerben főszabály lett - vélhetőleg az alulfinanszírozottság miatt - és 2017 óta megbontva ráadásul múködési és felhalmozási célú formában jelenik meg. Kérdés tehát, hogy a finanszírozás változása hogyan hatott az egyes közszolgáltatások minőségi megítélésére.

Megjegyzendő ugyanakkor, hogy a változások, átalakítások mércéje nem egyértelmú. Általában kimondva, kimondatlanul több szempont is munkál egyszerre, melyeket "hivatalosan” értékként határoznak meg, viszont egymással konkurálhatnak. A fogyasztói elégedettség mellett ez lehet a rendelkezési jogok, a vagyoni viszonyok, az eredményelosztás módjának megváltoztatása. 
Más kutatásainkból tudjuk, hogy az ágazati közszolgáltatások hazai átalakításai során ${ }^{3}$ kifejezetten ez volt a helyzet a 2010-es években. Jelen esetben azonban csak azt vizsgáljuk, vajon a fogyasztói szempont játszott-e szerepet, illetve érvényesült-e a változások óta eltelt időszak szociológiailag mérhető tapasztalatai alapján. Hipotézisünkkel összhangban, ha nemleges választ kapunk, az a mi általunk vázolt összefüggésben erősíti a más motiváció létezésének valószínúségét. Mindenesetre nem vonunk le olyan következtetést, hogy az átalakítás hasztalan lett volna, hiszen ilyet csak a tényleges célokkal összefüggésben lehet kimutatni.

Miként azt a tanulmány eleji mottónk mutatja, bizonyos döntéshozatali környezetben a célok igazolására elegendő a működőképesség valószínúsítése, az átalakítás valódi motivációit akár egy általános hivatkozással homályban is tartják. Értelemszerûen ebben a rendszerben nem teljes és nem nyilvános közpolitikai ciklusba ágyazódik be az átalakító elképzelés kialakítása és érvényesítése.

A fogyasztói elégedettségnek, illetve hiányának ugyanakkor ilyen körülmények között is van jelentősége. Ha a döntések hatékonyak is célracionális értelemben, a társadalmi eredményesség közszolgáltatások szervezése tekintetében mégis csak az, ha egyúttal a közösségi cél, a fogyasztói jólét javul. Ennek tükrében értékeljük a továbbiakban az elégedettségi adatokat, adatbázisaink elemzése útján.

\section{EREDMÉNYEK}

Az elmúlt években jelentôsen átalakultak a helyi önkormányzati szerepek az új jogszabályi környezetnek és a helyi közfeladati kör változásának következményeként. Ennek eredménye, hogy ma már másképp kell gondolnunk a magyar helyi önkormányzatokra, mint korábban. A decentralizáció új értelmet vett.

A változások az új önkormányzati törvény (továbbiakban: Mötv) ${ }^{4}$ elfogadásával kezdődtek, amely számos korábbi feladatot központi kormányzati hatáskörbe utalt, azaz csökkentek az önkormányzati feladatok. Túlmenően ezen a megmaradókkal kapcsolatos felelősségi köröket is a korábbitól eltérően osztották meg. Így a hulladékgazdálkodás területén 2012 után számos alkalommal módosult a szabályozás, ${ }^{5}$ amely során a helyi önkormányzatok elvesztették korábbi ármegállapító hatáskörüket, és egy zárt szolgáltatási struktúra alakult ki, melynek legfőbb szereplője az állami tulajdonú Nemzeti Hulladékgazdálkodási Koordináló és Vagyonkezelő Zrt. lett, ezzel biztosítva az egész országra kiterjedő egységes árszabályozást és számlázást. A települések szerepe viszonylag kiüresedett, de fogyasztóvédelmi szempontból a lakossági panaszok náluk is lecsapódtak, mint ahogy a 2. ábra is mutatja ezt a számlázás tekintetében, mikor is a válaszadók $64 \%$-a szerint állandóan vagy időszakosan nagy késés tapasztalható. 
2. ábra. A lakosság számára a hulladékkezelési közszolgáltatás számlázása hogyan valósul meg a településen?

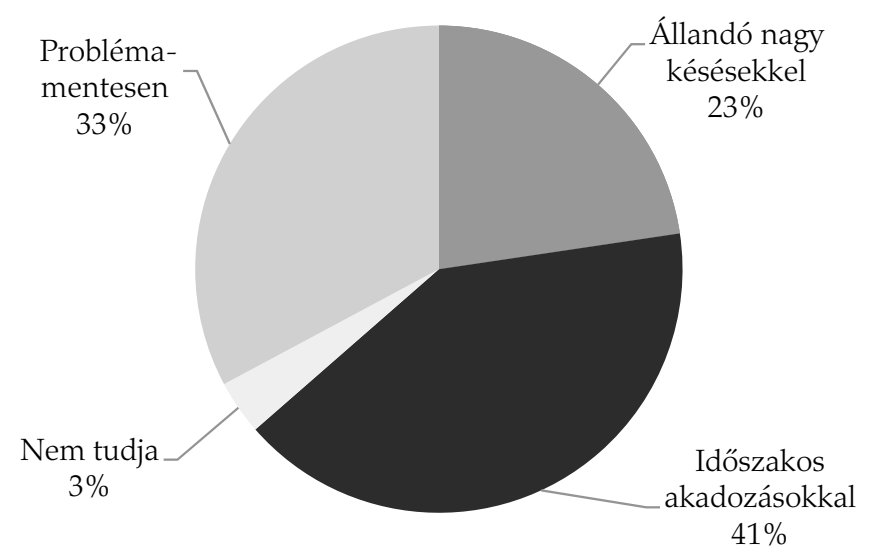

Forrás: önkormányzati felmérés, 2018 alapján, a szerzők

Sok más egyéb szabályozási, közfeladat-ellátási változásban kimutathatók az állami és az alsóbb szintű kormányzatok közötti hangsúlyok központi szint felé való eltolódása. Így a víziközmú szolgáltatás államosításával lényegesen megváltozott az ágazati szabályozás egy további fontos helyi önkormányzati szervezésú szolgáltatási területeken (Horváth-Péteri, 2013.). Alapvetően egyfelől a magánszektor kiszorításáról van szó a közfeladat ellátásából, másfelől az önkormányzati tulajdonosi szerepek átértékeléséről, melynek ára sokszor a döntési (szerződéskötési, ár-megállapítási, szolgáltatás-szervezési) jogkörök korlátozása. A jelenség érdekessége, hogy önmagában az egyes változtatások racionális közfeladat-ellátási megoldásnak mondhatóak, ugyanakkor együttesen, a helyi közfeladatok szinte valamennyi részére kiterjeszkedő és azok finanszírozását is érintő szabályozások jelentősen tovább csökkentették a helyi önkormányzatok érdemi szerepét.

Nyilvánvaló ugyanakkor, hogy ezeknek az átalakításoknak fogyasztói céljai sokkal kevésbé voltak. A vállalati erőforrások átcsoportosítása, a tulajdoni szerkezet átalakítása sokkal nagyobb motivációt jelentett. E körülmények mutatják egyben vizsgálódásunk értelmezési tartományának határait.

Az alábbiakban további, egyes humán közszolgáltatások minőségére vonatkozó adattáblákat láthatunk. A kutatás hipotéziseként azt állítottuk, hogy a feladatfinanszírozás kevésbé fogyasztóbarát, mely a közszolgáltatásokkal való elégedettséggel, a minőség javulásával mérhető. Az új finanszírozási forma bevezetésével a közszolgáltatások minőségének egységesítését, javítását és az alulfinanszírozottság megszüntetését tûzte ki célul a kormány. Megállapítható, hogy a vizsgált 7 közszolgáltatás esetében - ahol talán a legnagyobb a la- 
kosság érintettsége - a válaszadók szerint leginkább romlott, de legalábbis nem javult a közszolgáltatás minősége a nagy átalakítás utáni többéves időszak személyes tapasztalatai alapján.

3. ábra. Az óvodai közszolgáltatás minőségének megítélése településkategóriák szerint

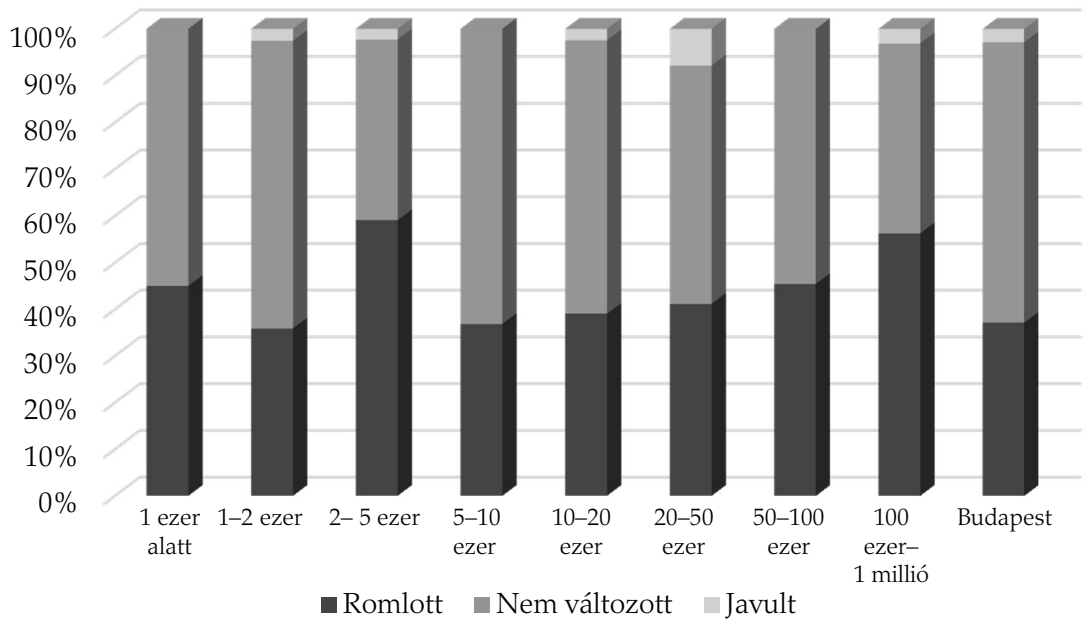

Forrás: lakossági felmérés, 2017 alapján, a szerzők

Az alapfokú oktatási feladatellátás centralizálásával, a helyi önkormányzatoknál csupán az óvodai és bölcsődei közszolgáltatások megszervezése maradt. Az óvodai ellátás megszervezése minden olyan településen kötelező, ahol legalább nyolc óvodáskorú gyermek él, továbbá, ha a szülők ezt igénylik. A bölcsődei szolgáltatást minden 10000 fő lakónépességet meghaladó településen köteles az önkormányzat megszervezni, míg a többi számára csak fakultatív. ${ }^{6}$

A feladat volumenét mutatja, hogy KIR-STAT 2017-es adatai alapján az országban összesen 2191 településen 4694 feladatellátási helyen nyújtották az óvodai ellátást, amely a lakosság érintettségét jól tükrözi (KJ 1, 2018: 53.). A lakossági megkérdezés eredményei mind az óvodák, mind a bölcsődék esetében azt mutatják, hogy az ellátás színvonala az elmúlt években romlott vagy nem változott. Különösen érdekes kiemelni, hogy az óvodák esetében a 2-5 ezer, míg bölcsődék esetében a 2 ezer fő alatti lakosságszámú településeken éreztek leginkább romlást.

A két közszolgáltatás esetében közel azonos okokra vezethetők vissza a rossz eredmények. Egyfelől a férőhely-kihasználtság különbségeiből fakadó bevételkiesés a községi intézményeknél jelentős, így a legkisebb településeken ezért nem éreznek javulást. Másrészt a jelenlegi finanszírozási rendszer a forrásmaximalizáció miatt a lehetséges csoportlétszámok teljes feltöltésére ösztönzi az 
intézményeket, amely a szakmai oldal hátrányára válhat, s a szülők úgy érzik, hogy kevesebb figyelem jut gyermekeikre. A szabályozás tehát az intézmények anyagi érdekét szembe helyezi a minőségi paraméterekkel. E mellett probléma az is, hogy a látványosabb felújításokat is finanszírozni tudó felhalmozási célú források elsősorban pályázati úton érhetők el, amely nagyban a fenntartók anyagi helyzetétől is függ. Ráadásul az elmúlt években a szolgáltatások iránti igény nőtt, mely a csoportok túltelítettségéhez és az óvodapedagógusok, gondozók részleges hiányához is vezetett. Ez utóbbi szakemberhiány jelenti talán a legnagyobb gondot a rendszerben (KJ 1, 2018: 48.). Egy tapasztaltabb munkaerő átlagos bére sokkal magasabb, mint egy pályakezdőé, amelyet nem engedhet meg minden település magának. Mindez azt eredményezheti, hogy a tapasztaltabb szakemberek, akik a szociálisan érzékenyebb gyermekek nevelésében jobban tudnának segíteni, nem maradnak az adott kistelepülésen, mert a jobb anyagi helyzetben lévő önkormányzatok vonzóbb ajánlatot tudnak tenni számukra. Érdekesség, hogy 20-50 ezer lakosságszámú települések kategóriában egymás mellett érzi a megkérdezettek egy-egy része, hogy romlott és kismértékben javult is az óvodai szolgáltatás, amely azzal magyarázható, hogy a városokon belül jelentős minőségi és hozzáférési különbségek vannak. A privilegizált helyzetben lévő, felújított óvodák iránt érezhetően nagyobb az igény, amelyek maximális kapacitáson üzemelnek, míg tipikusan a lakótelepi, fel nem újított intézmények kisebb csoportlétszámmal múködnek.

A lakossági felmérés szerint a városok többségében az önkormányzati fenntartású intézmények mellett egyházi és alapítványi fenntartású intézmények is mûködnek, amelyet a megkérdezettek infrastrukturálisan jobban ellátottnak ítéltek meg.

4. ábra. A közmúvelődési közszolgáltatás minőségének megítélése településkategóriák szerint

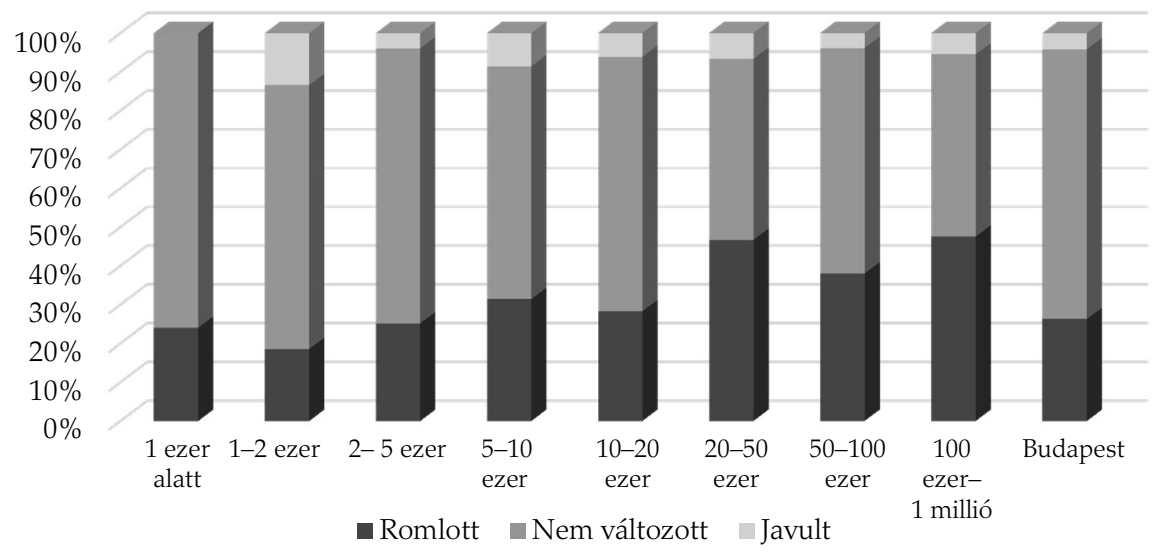

Forrás: lakossági felmérés, 2017 alapján, a szerzők 
A közmúvelődési szolgáltatások igénybevételének lehetősége egyik fontos eleme az élhető településeknek, a lakosság szabadidejének megfelelő eltöltésének. Bár az elmúlt években a közmúvelődési szolgáltatásokra nyújtott források nagysága nőtt, azok jellemzően pályázati típusúak, melyből nem egyenlően részesültek a települések. Így az állami normatíva mellett azon múlik a szolgáltatás minősége, hogy az adott önkormányzat mennyit tud saját forrásból mellétenni. A diagramból jól látható, hogy a megkérdezettek közül a legkisebb településeken élók érezték leginkább azt, hogy romlott vagy nem javult a szolgáltatás színvonala, amely egybevág azzal, hogy az 1000 fő alatti településeken a finanszírozás 50\%-os múködési hiányt jelent, azaz a felét finanszírozza csak az állam. Bár a nagyobb településeknél az arány még magasabb is lehet, de az adóerő-képesség alapján keletkező többlet ezt némiképp kompenzálja. A rendszer másik problémája a minőségfejlesztés hatékonysága, melyet jól mutat, hogy 2017-ben csupán 55 minősített önálló költségvetési közmúvelődési intézmény múködött az országban.

\section{5. ábra. A szociális étkeztetés minőségének megítélése településkategóriák szerint}

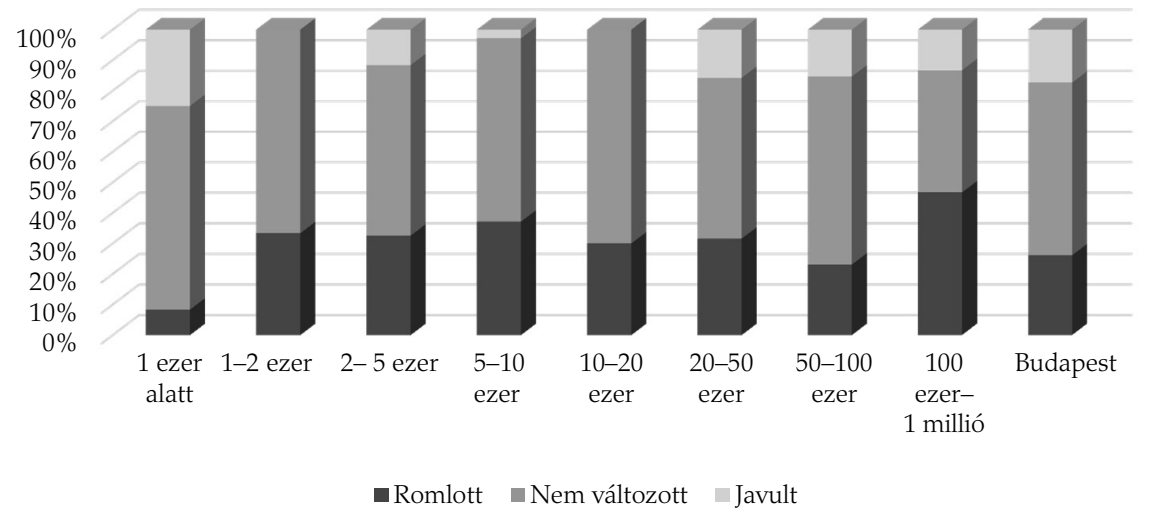

Forrás: lakossági felmérés, 2017 alapján, a szerzők

A szociális étkeztetés biztosításáról minden önkormányzatnak kötelessége gondoskodni, amennyiben ellátásra jogosult lakossal rendelkezik. A lakossági felmérés szerint a közszolgáltatás minőségében jelentős javulást nem érzékeltek a megkérdezettek, inkább a stagnálás és a romlás érzékelhető. Különösen az 1-2 ezer és a 10-20 ezer közötti lakosságszámú települések esetében (5. ábra).

Az ellátás sajátossága, hogy a finanszírozásban az állami normatíva mellett megjelenik az ellátott térítési díja. Az állami normatíva 2018-ban 220 forint/nap/fő volt, könnyen beláthatjuk, hogy önkormányzati kiegészítés, illetve térítési díj nélkül nem sokra elegendő, nincs tekintettel az előállítás, szállítás valós költségeire, illetve arra sem, hogy pont egy szociálisan érzékeny társa- 
dalmi réteg ellátásáról van szó, akiktől nehezen várható magasabb összegû hozzájárulás. A támogatás tehát nem tesz különbséget a település mérete és adóerő-képessége között. A minőségi romlás érzékelésében egy újonnan megjelenő gyakorlat is szerepet játszhat, miszerint egyre több településen múködtetnek népkonyhát szociális étkeztetés helyett. Az előbbire ugyanis sokkal enyhébb minőségi követelmények vonatkoznak, így az alapanyagokkal jobban tudnak ,játszani”, mint a másik esetben. Tovább árnyalja a problémát az az önkormányzati gyakorlat, hogy magán szereplőkkel oldják meg az étkeztetés biztosítását, amelyeknél adott esetben sok panasz érkezik a szolgáltatóra, akik nem feltétlenül tekintik igazi piaci szolgáltatásnak a szociális étkeztetést (KJ 1, 2018: 114.).

\section{6. ábra. Az idősek nappali ellátás minőségének megítélése településkategóriák szerint}

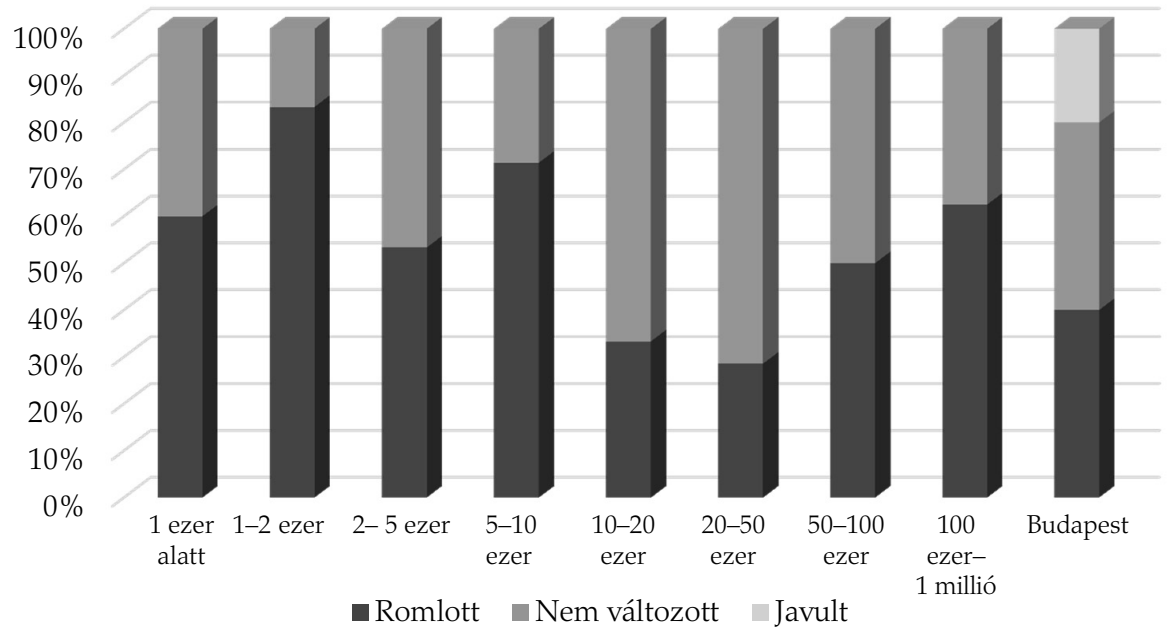

Forrás: lakossági felmérés, 2017 alapján a szerzők

A szociális alapszolgáltatások másik formája az idősek nappali ellátása, amelyet minden olyan települési önkormányzat köteles biztosítani, amelynek területén legalább háromezer fő él, ugyanakkor az elöregedő társadalmi folyamatokra tekintettel a kisebb településeknél is fokozottan jelentkezik az igény (Fónai, 2014: 320.). A megkérdezettek válaszából kiderül, hogy a minőségi javulás szinte egyáltalán nem volt megfigyelhető a szolgáltatás terén, csupán a fővárosban volt érzékelhető. Az okok itt is a finanszírozásban és az elavult infrastruktúrában keresendők. Az állam által nyújtott támogatás a kiadások csak egy részét fedezi, az önkormányzati felmérés szerint volt ahol ez az arány kevesebb, mint 14\% volt, de sehol sem érte el a 40\%-ot (Javaslat, 2018: 142.). Így az önkormányzatok szúkös keretei, s az ellátottak térítési díja gátat szab a mi- 
nőségi javulásnak. Ugyanakkor ezen közszolgáltatás esetében nagyon fontos szerepe van az intézményi infrastruktúrának, a különböző programoknak. A romlást legkisebb mértékben 10-50 ezer lakosságszámú településeken, jellemzően a közepes magyar városokban érzékelték.

7. ábra. A házi segítségnyújtás minőségének megítélése településkategóriák szerint

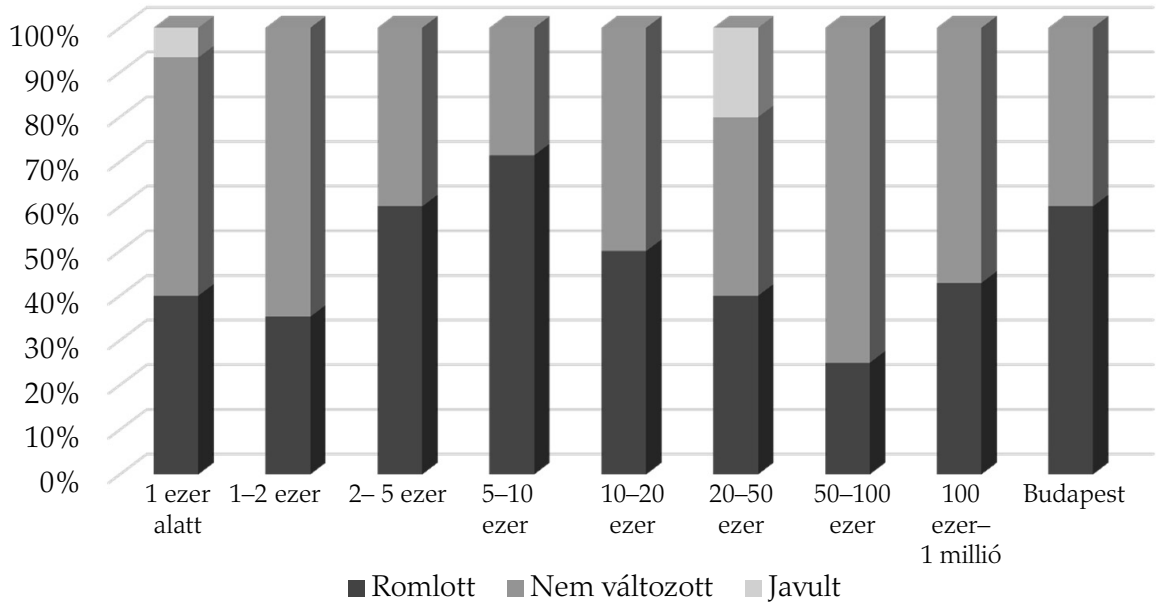

Forrás: lakossági felmérés, 2017 alapján, a szerzők

A szociális alapszolgáltatások közül nagyságrendjét tekintve kiemelendő a házi segítségnyújtás intézménye is, amelyet 2018-ban egy-egy munkanapon átlagosan 83 ezer fő vett igénybe, mely létszám a második legnagyobb ellátotti kört jelenti a szociális étkeztetés után. ${ }^{7}$ A lakossági vélemények (7. ábra) a többi szociális ellátási formához viszonyítva nagyon hasonlóak, ahogyan a finanszírozás is nagyon hasonló képet mutat. Önkormányzati támogatás nélkül nem tudnak az intézmények múködni a jogszabály által meghatározott minimumfeltételeknek megfelelve. A MÁK adatai szerint országosan a kisebb településeken a múködési költségeknek átlagosan a felét, míg a 40 ezer fő feletti településeken több mint $80 \%$-át a a települések saját forrásaikból biztosítják (Javaslat, 2018: 134.). E szakterületen is komoly gondokat okoz a munkaerőhiány az önkormányzati felmérés adatai alapján. Az önkormányzatok egy nagyobb része ezt a közmunkaprogramban foglalkoztatottakkal kívánta orvosolni, mivel a szociális segítség feladatai elláthatók e formában, csupán a személyes gondozáshoz szükséges szakképzett személyzet. Így a minőség stagnálásában, romlásában e megoldásnak is szerepe lehet. Csupán a 20-50 ezer lakosságszámú települések esetében érezhető javulás, mely talán annak köszönhető, hogy e kategóriában a minimumszint felett plusz szolgáltatásokat is kínálnak saját forrásból a fenntartók. 
A szolgáltatásszervezési változásoknak ezúttal is csak a fogyasztói szempontjáról mondhatjuk vizsgálatunk keretei között, hogy kevéssé áll előtérben. Az államháztartáson kívüli megoldások súlyának és szerepének átalakítása ugyanolyan vagy nagyobb horderejü motívuma lehetett az átalakításoknak (Hoffman, 2016: 350-351.), ezért hatékonytalanságról általános értelemben még nem feltétlenül beszélhetünk amiatt, mert az igénybe vevők érdekeltsége hátrébb sorolódott.

8. ábra. A helyi közparkok és játszóterek fenntartásának minőségi megítélése településkategóriák szerint

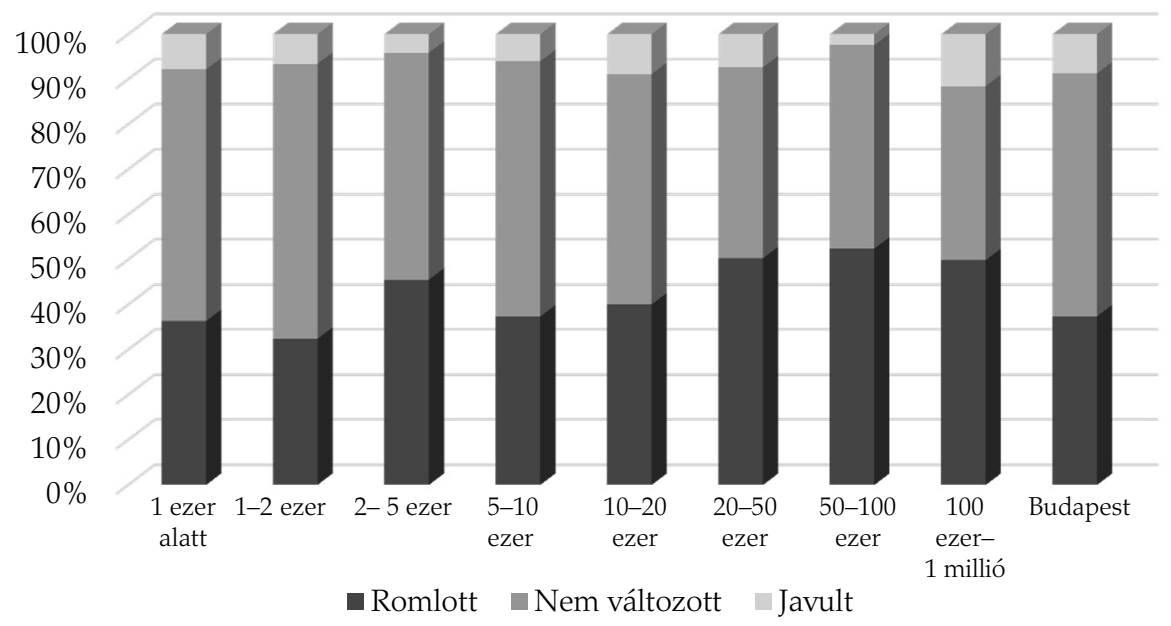

Forrás: lakossági felmérés, 2017 alapján, a szerzők

A lakosság közérzetére, a település élhetőségére vonatkozóan a közmúvelődési feladatok mellett a helyi közparkok, játszóterek, zöldterületek megfelelő biztosításának fontos szerepe van. A közterületek megfelelő fenntartása minden önkormányzat kötelező feladata. A lakossági felmérés alapján a megkérdezettek $42 \%$-a úgy érzi, hogy romlott, míg 51\%-a szerint nem változott minőségileg a zöldterületek fenntartása az elmúlt években.

Mindezek mögött jelentős finanszírozási problémák húzódnak meg. Mind a költségvetési adatokból, mint az önkormányzati felmérésből az derül ki, hogy a kisvárosok esetében a zöldfelület fenntartására kapott összeg jelentősen alultervezett a valós költségekhez képest. Ennek több oka van, egyfelől a kisebb városok az adóerő-képesség miatt nem részesülnek teljes támogatási összegben, másfelől városi minőségú igények merülnek fel a közterületek fenntartásában, melyek magasabb költséggel járnak. Így általános megoldássá vált - a többi településkategória esetében is -, hogy közfoglalkoztatottakat alkalmaz- 
nak a közterületek fenntartására. A közepes és nagyvárosok esetében a finanszírozás még rosszabb, jellemzően nem is kapnak hozzá állami forrást a magas adóerő-képességük miatti beszámításra tekintettel. A minimális szintû javulás a különféle uniós forrásból megvalósuló fejlesztéseknek köszönhető. Egyedül a kistelepülések esetében tapasztalható finanszírozási szempontból, hogy a normatíva épp elegendő a minimális feladatok elvégzéséhez. Ugyanakkor a kisebb településeken is egyre inkább nő a szebb környezet iránti igény, de a fejlesztésekre nem nyújt fedezetet a forrás.

9. ábra. Az utóbbi 5 évben kérdezték az alábbi közszolgáltatásokkal kapcsolatos elégedettségéről?

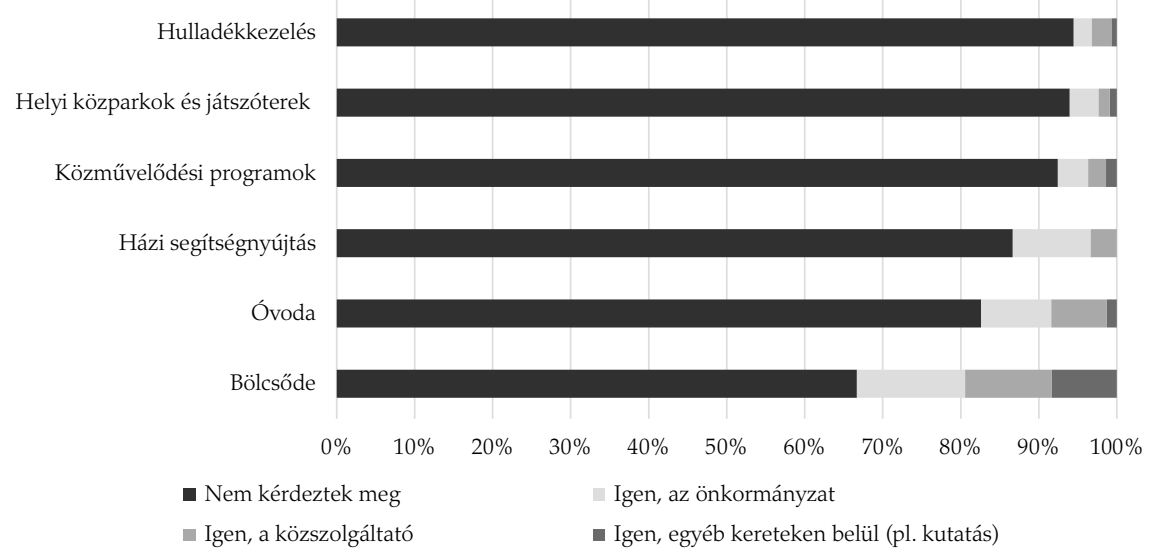

Forrás: lakossági felmérés, 2017 alapján, a szerzők

Mint az előzőekben láthattuk a lakossági vélemények szerint a vizsgált közszolgáltatások minősége az utóbbi években elenyésző mértékben nőtt, legtöbb esetben stagnált, vagy rosszabb esetben még romlott is. Bár ennek jellemzően finanszírozási oka van, érdemes azt is megvizsgálni, hogy egyáltalán mennyire fogyasztóbarát, minőségorientált a szolgáltatásszervezés. A 9. sz. ábrán a lakossági kérdőíves felmérés azon kérdésére adott válaszok láthatók, hogy az elmúlt öt évben kíváncsi volt-e bárki a lakosság közszolgáltatásokkal való elégedettségére. Talán nem meglepő az eredmény, amely szerint jellemzően sem az önkormányzat, sem a közszolgáltató nem mérte fel a területén élők elégedettségét. Ha azt vizsgáljuk, hogy hol kérdezték meg inkább a lakosokat, akkor azt láthatjuk, hogy a kisebb településkategóriáknál ez a szám magasabb volt, tehát a település méretével egyre távolabb kerül a fogyasztó a szolgáltatás szervezőjétől. Nagyon hasonló eredményeket mutat a lakosság helyi döntésekbe történő bevonása is (1. melléklet), miszerint a nagyobb településkategóriákban egyre kevésbé érzik azt a lakosok, hogy bevonnák őket a helyi döntések meghozatalába. 


\section{ÖSSZEHASONLÍTÁSBAN}

A következőkben az európai bizottsági "Quality of Life in European Cities" címú felmérés adatai alapján össze is vetettük a magyarországi településekre vonatkozó eredmények egy részét a nemzetközi tendenciákkal. A bizottság kérdései elsősorban a város „élhetőségére" irányultak különböző területeken, ezért a magyarországi kutatásunk köréből is ezen igény kielégítését célzó közszolgáltatásokat vettük az összehasonlítás alapjául. Ilyen módon három fő területet vizsgáltunk: közparkok/zöld területek állapota; közmúvelődés/kulturális létesítmények szolgáltatásai; hatósági szolgáltatások hatékonysága.

10. ábra. Zöld területek állapotával való elégedettség százalékos aránya 300 ezer fő alatti lakosságszámú európai városokban 2015-ben

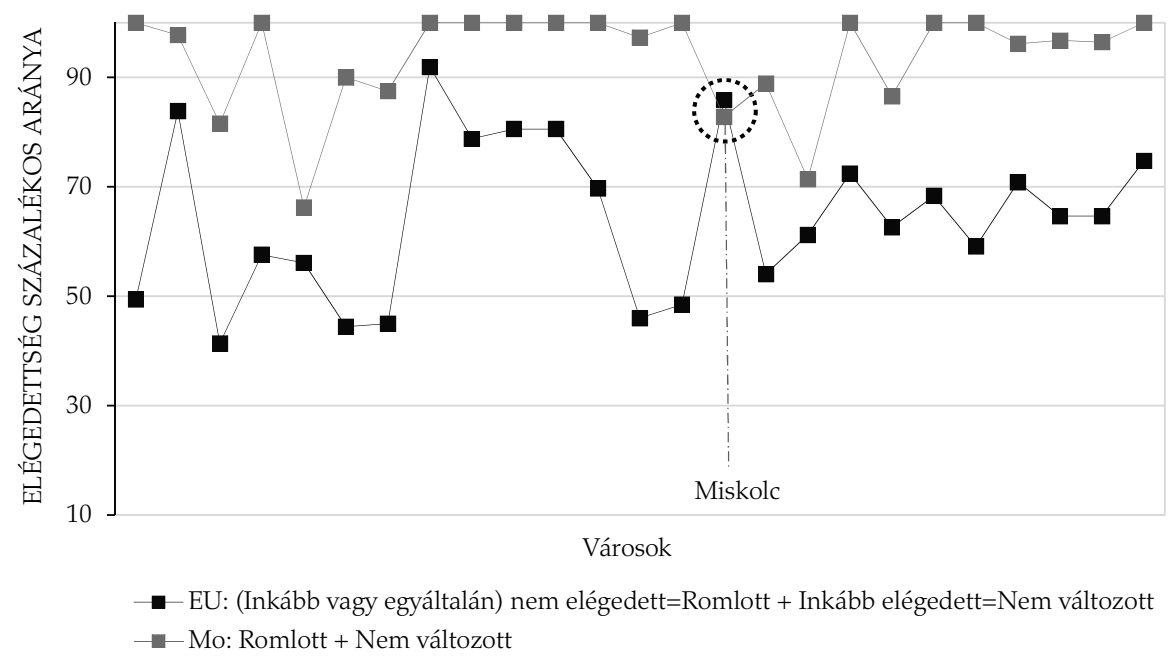

Forrás: EC, 2010; EC, 2013 és EC, 2016, valamint lakossági felmérés, 2017 alapján, a szerzők

A bizottsági felmérésben vizsgált 79 város közül a 300 ezer fő alatti lakosságszámú városok (mintegy 25 város) ${ }^{8}$ adatait dolgoztuk fel, mivel ezek tekinthetôk összehasonlítható mintának a legnagyobb, illetve legkiterjedtebb közszolgáltatási funkcióval rendelkező magyar településekkel. Méretük, illetve feladatkörük alapján a megyei jogú városok, illetve a 100 ezer fő feletti lakosságszámú budapesti kerületek képezték az összehasonlító vizsgálat magyarországi bázisát (lakossági felmérés, 2017 adataiból). A nemzetközi felmérés településenként is reprezentatív; az Európai Bizottság nevében kezdeményezett telefonos interjú útján minden városban 500 lakost anyanyelvükön kérdeztek meg, eltérő társadalmi és demográfiai csoportokból válogatva. A ma- 
gyarországi felmérés összességében, a kiválasztott településcsoportra nézve tekinthető reprezentatívnak.

Bár a magyar településeket érintő kérdésfeltevések alapvetően a közszolgáltatások minőségének változására irányultak, az ezekre adott lakossági válaszokból is le lehet vonni a lekérdezéskori elégedettségi állapotra vonatkozó megfelelő következtetéseket, amelyek így összehasonlíthatóak lesznek a bizottsági interjúk eredményeivel. (A nemzetközi és a hazai eredmények megfeleltetési rendszerét alább az egyes ábráknál mutatjuk.) A zöldterületek állapotával való lakossági elégedettség összevetésének eredményét a 10. ábra mutatja.

A magyar kérdőívektől némileg eltérően, az európai bizottsági lekérdezés nem kifejezetten a közparkokra irányul, ugyanakkor a megkérdezettek nézőpontjából a fókuszált lakossági igény mindkét esetben a város zöldterülettel való ellátottsága, illetve annak minősége. A magyarországi nagyvárosok körében a megkérdezettek 45,5\%-a úgy érzi úgy, hogy romlott, míg 46\%-a szerint nem változott minőségileg a zöldterületek fenntartása az elmúlt években. A nemzetközi felmérés eredményei ezzel ellentétes tendenciát mutatnak.

\section{1. ábra. Zöldterületek állapotával való elégedettség nemzetközi összehasonlítása}

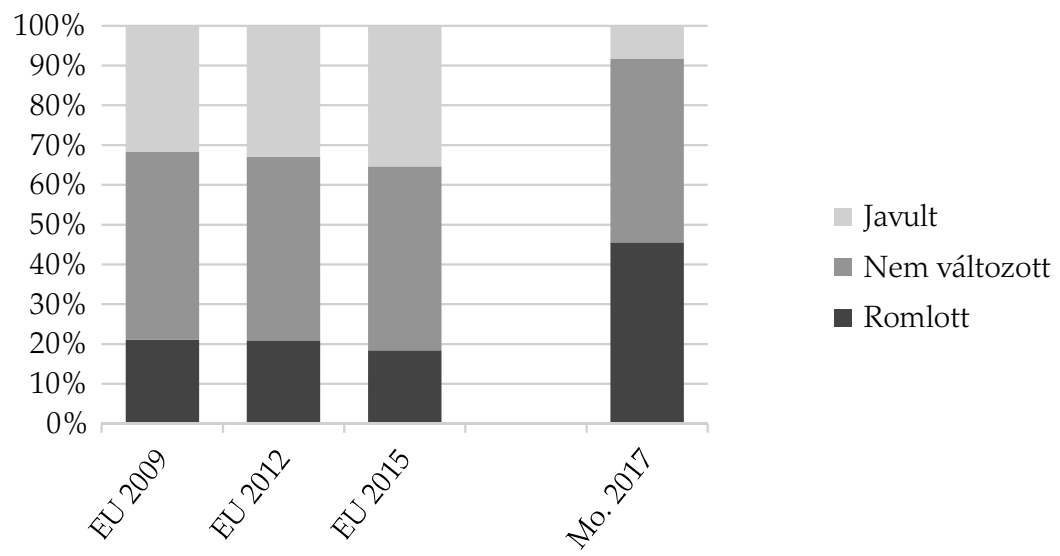

Magyarázat: a magyarországi felmérések esetében háromfokozatú, míg az európai bizottsági lekérdezésnél négyfokozatú skálán volt lehetőség a válasz megjelölésére. Ez utóbbit az alábbiak szerint feleltettük meg a magyarországi lekérdezés kategóriáinak: a közszolgáltatás minősége 1) Romlott = inkább nem elégedett + egyáltalán nem elégedett; 2) Nem változott = inkább elégedett; 3) Javult = nagyon elégedett.

Forrás: EC, 2010; EC, 2013 és EC, 2016, valamint lakossági felmérés, 2017 alapján, a szerzők

Az adatokat érdemes városokra lebontva is megnézni (figyelembe véve természetesen, hogy csak a nemzetközi felmérés tekinthetô városonként is teljes 
mértékben reprezentatívnak). Bár az elégedettségi arányok - földrajzi elhelyezkedés, gazdasági fejlettségi szint, természeti adottságok stb. függvényében - a magyar, illetve a nemzetközi településcsoporton belül is erős eltéréseket mutatnak, a zöldfelületek esetében mégis jól látszik, hogy az európai városokban érzékelhetően magasabb a közszolgáltatással nagyon elégedett lakosok aránya és alacsonyabb azoké, akik mérsékelten vagy egyértelmúen nem elégedettek. (Látható az is a 10. ábrán, hogy a két felmérés közös elemét képező Miskolc város esetében közel azonos az eredmény.) Hasonló eredményt látunk a kulturális létesítmények szolgáltatásaival való elégedettség összevetésénél is.

12. ábra. Kulturális létesítmények szolgáltatásaival való elégedettség nemzetközi öszszehasonlítása

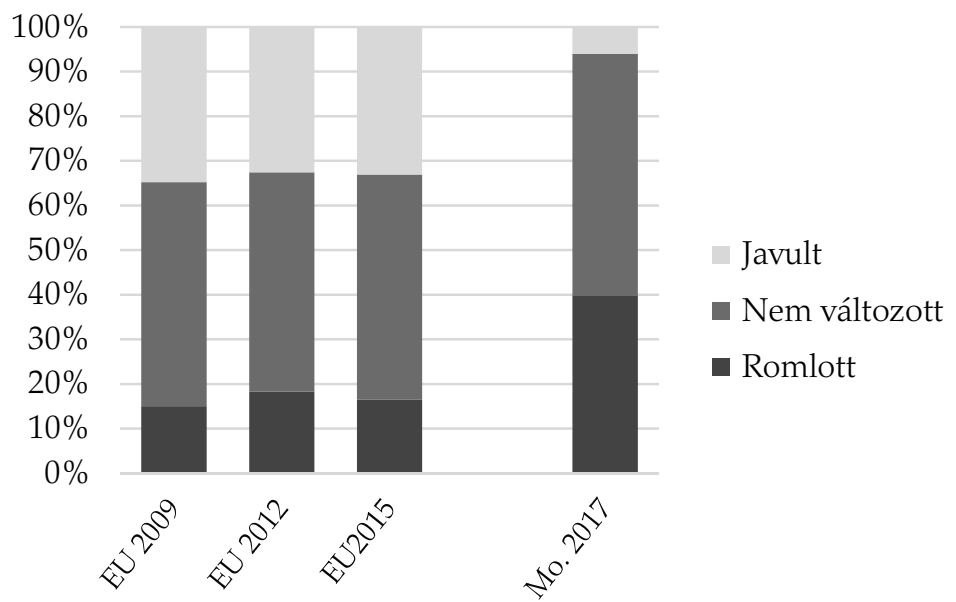

Magyarázat: a magyarországi felmérések esetében háromfokozatú, míg az európai bizottsági lekérdezésnél négyfokozatú skálán volt lehetőség a válasz megjelölésére. Ez utóbbit az alábbiak szerint feleltettük meg a magyarországi lekérdezés kategóriáinak: a közszolgáltatás minősége 1) Romlott = inkább nem elégedett + egyáltalán nem elégedett; 2) Nem változott = inkább elégedett; 3) Javult = nagyon elégedett.

Forrás: EC, 2010; EC, 2013 és EC, 2016, valamint lakossági felmérés, 2017 alapján, a szerzők

A kulturális létesítmények esetében az európai bizottsági felmérés a koncerttermek, színházak, múzeumok és könyvtárak szolgáltatásaival való elégedettségre irányul, amelyik - tekintve, hogy e létesítmények nagyobb részének múködtetésében vagy legalábbis a szükséges feltételek biztosításában a helyi önkormányzat jellemzően más városokban is szerepet vállal - összehasonlítható a magyar kérdőív szerinti közmúvelődési szolgáltatásokkal (példaként a 
magyar kérdőív is ugyanezt az intézményi kört említi). A vizsgált magyarországi városokban a megkérdezettek 40\%-a érzi úgy, hogy romlott, míg 54\%-a szerint nem változott a közművelődési szolgáltatások minősége az elmúlt években (12. ábra).

A nemzetközi felmérés ugyanazon módszerrel, kérdésekkel és lakossági csoporttal lekérdezett adatai 2009, 2012 és 2015 évekből is rendelkezésünkre állnak, így a lakossági elégedettség változásának dinamikáját nemzetközi szinten is meg tudjuk határozni. A zöldterületek állapota esetében az összesített elégedettségi átlag 2009 és 2015 között 4,62\%-kal nőtt és e növekedés a "nagyon elégedettek" aránya emelkedésének tudható be (az „inkább elégedett” kategória gyakorlatilag nem változott), ami egyértelmúen pozitív eltérést mutat a magyarországi tendenciáktól.

A kulturális létesítmények szolgáltatásainál a nemzetközi elégedettségi arányok alakulása alapvetően szintén pozitív, igaz, nem olyan egyenletes mértékú, mint a zöldterületek esetében. A 10. ábra szerint az összesített elégedettségi átlag 2009 és 2015 között nagyjából konstans, csekély mértékú negatív kilengést mutatva 2012-ben, amely viszont 2015-re már visszafelé fordul. Ugyanakkor az egyes városokat nézve az elégedettségi változás „kilengése” nagyobb mértékü, mint a közparkok esetében. Miskolc számai csökkenő tendenciát mutatnak.

A hatósági szolgáltatások megítélése kedvezőbb a vizsgált magyar városcsoport válaszadói körében, mint az előző két közszolgáltatásnál. Összhangban van mindez Kákai és Vető megállapításával, amely szerint a hatósági ügyintézés az egyetlen olyan terület, ahol az önkormányzati feladatellátás 2013-as átszervezésének mérlege pozitív (Kákai-Vető, 2019: 33.). A két felmérés eredményének összevetését a 13. ábra mutatja.

13. ábra. Hatósági szolgáltatásokkal való elégedettség két magyarországi felmérés alapján

Kákai-Vető felmérés

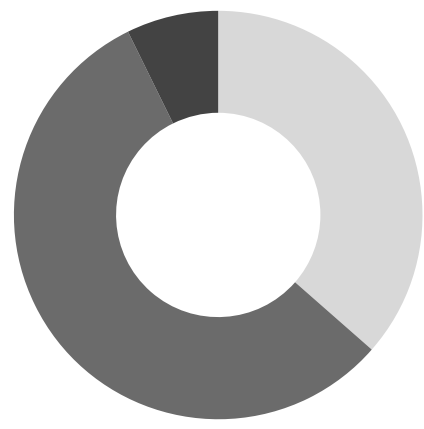

BM lakossági kérdőíves felmérés

Javultak a körülmények

- Nem történt változás

- Romlottak a körülmények

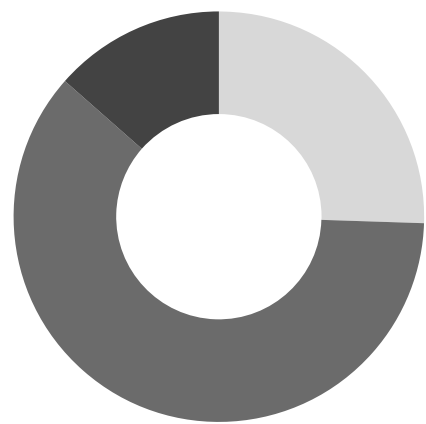

Forrás: lakossági felmérés, 2017 és Kákai-Vető, 2019 alapján, a szerzők 
14. ábra. Hatósági szolgáltatások hatékonyságával való elégedettség a 300 ezer fő alatti lakosságszámú európai városokban 2015-ben - összehasonlítás magyar adatokkal

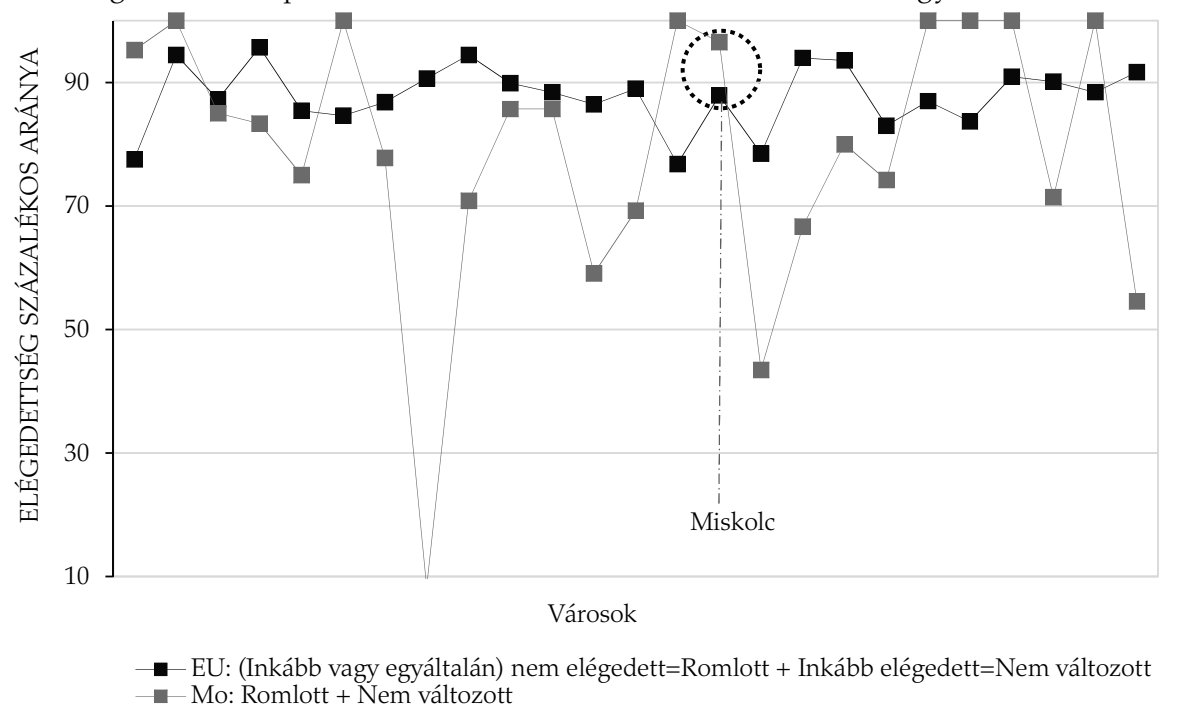

Forrás: EC, 2010; EC, 2013 és EC, 2016, valamint lakossági felmérés, 2017 alapján, a szerzők

A hatósági szolgáltatások magyarországi elégedettségi eredményeinél a nemzetközi adatokhoz viszonyítva sem látható olyanfajta egyértelmúen negatív eltérés, mint ezt a zöldfelületek és a kulturális létesítmények esetében tapasztalhattuk (14. ábra). (Hozzá kell tennünk, a magyar felmérés kifejezetten az önkormányzati feladatkörben lévő hatósági ügyintézésre fókuszált, míg a nemzetközi általában a településen elérhető hatósági szolgáltatásra.)

\section{KÖVETKEZTETÉSEK}

Kákai László és Vető Balázs 2019-es tanulmánya a hazai önkormányzati változásokat a centralizációval ellenpontozva vizsgálta, és arra a következtetésre jutott, hogy lakossági vélemények szerint a központi szervezéssel az ellátások nem kerültek jobb kezekbe. A mi vizsgálatunk fókuszában nem a kifejezetten „átszervezett” szolgáltatások álltak, hanem a kizárólag pénzügyi eszközök útján központosított feladatokat vettük alapul. E, „helyben hagyott” funkciókörök tekintetében sem látszik, hogy a változás érzékelhető pozitív hatással járt volna az ellátás színvonalára nézve. Inkább az ilyesmit nem érzékelő válaszok vannak minden vizsgált témát illetően túlnyomó többségben. 
Nemzetközi összehasonlításban az derült ki, hogy a közösségi elégedettség alacsony szintje nem sorsszerü, sem az Európai Unió összes, sem pedig a Magyarországhoz hasonló fejlettségű országai körében, vélhetően ezért, hogy a konkrét eredmények magyarázata tekintetében belső magyarázó okok mindenképpen szerepet játszanak.

Fogyasztói szempontból összességében érdemben nem igazolható, miszerint a helyi önkormányzati rendszer átalakítása után jobb lenne a feladatellátás színvonala. A közszolgáltatások szervezésének társadalmi eredményessége bizonnyal nem javult, sőt, az adatok szerint mindenféle összevetésben jellemzően romlott.

Nem következik ebből azonban, hogy maga a centralizálás idejét tekintve „elhamarkodottnak", célját illetően „értelmetlennek”, netán kivitelezésére figyelemmel „elhibázottnak" lenne minősíthető. Mindez ugyanis az átalakítási szándék motiváltságától függ. Ha a fogyasztói igények kielégítésétől eltérően a szándék elsődlegesen az érdekeltségi viszonyok átalakítása, az irányítási rendszer megváltoztatása, a hálózatos szolgáltatások esetében az üzleti eredmény átcsoportosítása és a tulajdoni hányadok kivásárlása volt - akkor a költségvetési rendelkezési jogok új keretek között való értelmezése, redisztribúciója, akár hatékonynak is nevezhető.

Egyébiránt a múködőképesség fennállt, a tényleges átszervezési motivációk és célok pedig a döntés elfogadtatásakor kimondatlanul maradnak. Éppen úgy, miként azt a tanulmányunk mottójául választott életkép oly egyszerüen összefoglalja.

Így nézve adataink értelmezése hozzáadott értéket jelent a korábbi felfogásokhoz képest, amelyek a változást a magyar decentralizáció kudarcaként (Pálné, 2016), a centralizáció tarolásaként (Gajduschek, 2012., Horváth M., 2012), avagy az önkormányzati politika 2010-2012-es fordulatán átívelő sodródásaként (Kákai-Vető, 2019) fogták föl. A kétségkívül nem fölösleges múltba nézés mellett azonban egy immár csaknem évtizedes gyakorlat múködési praktikájának értékelése joggal és okkal kerülhet ugyancsak az elemző figyelem előterébe.

Jelen tanulmány alapján erről azt állapíthatjuk meg, hogy a helyi önkormányzati rendszeren belüli centralizációs változást, továbbá az ebben megnyilvánuló központosítás módját illetően a közösségi fogyasztói szempontok érvényesülése semmiképpen sem erősödött, inkább kifejezetten romlott. Az is igazolható, hogy a nemzetközi összehasonlítás nem mutat hasonló trendet, tehát ennek az értékvesztésnek az okai belső körülményekből származnak. Bizonnyal nem zárható ki ennek a hatásnak a - mi kutatásunk vállalási keretein már túlmutató - magyarázatai során, a jó előre megfontolt szakpolitikai számítás, azaz más gazdasági előny választásának vagy az erőforrások újraelosztásának szempontja. 


\section{MELLÉKLET}

1. melléklet. A lakosok bevonása a döntésekbe. Milyen mértékben tapasztalta ezt az önkormányzat munkájával kapcsolatban?

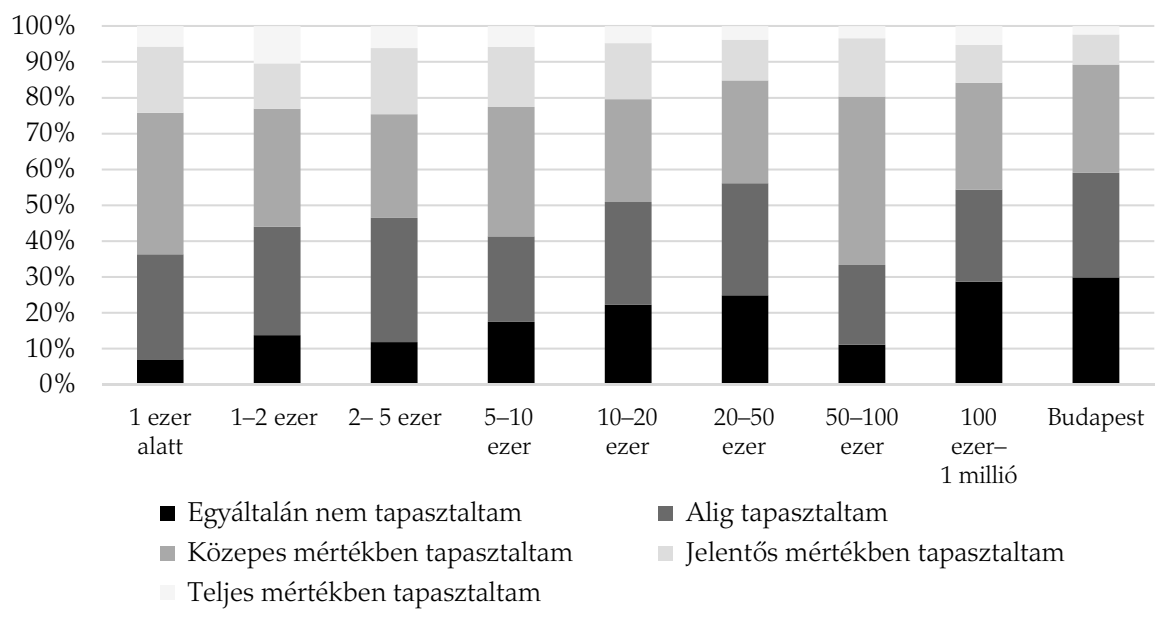

Forrás: lakossági felmérés, 2017 alapján, a szerzők

2. melléklet. Helyi kiadások alakulása a GDP\%-os arányában 2009-2018 között

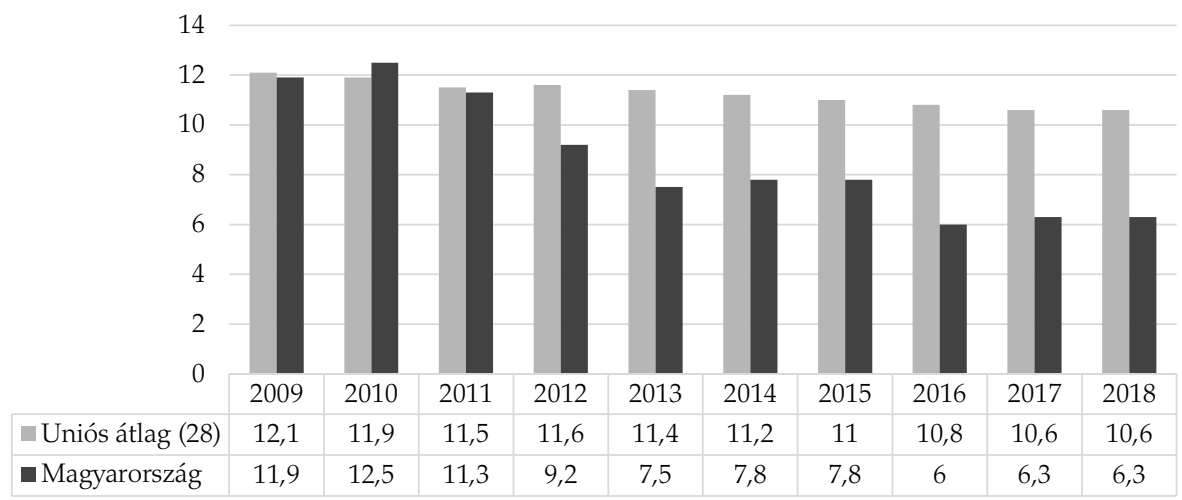

Forrás: az Eurostat (2018) adatai alapján, a szerzők

\section{JEGYZETEK}

1 Az adatok rendelkezésre bocsátásáért köszönettel tartozunk Cserneczky Tamásnak, a KÖFOP2.3.4-VEKOP-15-2016-00002 Helyi Versenyképesség-fejlesztési Kutatási Program, 1-3. célterület szakmai koordinátorának és a Belügyminisztérium Önkormányzati Államtitkárságának. 
2 Ezzel régi reminiszcenciákat (Vági, 1982) ébresztve.

3 Lásd erről és összefüggéseiről ágazatonként: Horváth-Bartha, 2016.

4 Magyarország helyi önkormányzatairól szóló 2011. évi CLXXXIX. törvény.

5 Lásd a hulladékról szóló 2012. évi CLXXXV. törvény módosításait.

6 Egy 2017-es módosítás alapján 2020-ra minden olyan településen biztosítani kell e szolgáltatást, ahol a 3 év alattiak létszáma eléri a 40 főt, vagy ahol azt legalább 5 gyermek vonatkozásában a szülők kérik.

7 Az Igénybevevői Nyilvántartás (KENYSZI, TEVADMIN) adatai szerint.

8 2015-ben az alábbi 25 város: Aalborg (DK), Braga (PT), Bialystok (PL), Bordeaux (FR), Burgasz $(\mathrm{BG})$, Genf (CH), Groningen (NL), Irakleio (GR), Kassa (SK), Lefkosia (CY), Liege (BE), Lille (FR), Ljubljana (SI), Luxembourg (LU), Miskolc (HU), Newcastle (GB), Ostrava (CZ), Oulu (FI), Oviedo (ES), Piatra Neamt (RO), Rennes (FR), Reykjavik (IS), Rostock (DE), Strasbourg (FR), Verona (IT). 2009-ben és 2012-ben Genf és Reykjavik felmérésére nem került sor.

\section{IRODALOM}

Bailey, J. Stephen (1999): Local Government Economics: Principles and Practice. Macmillan Press, Houndmills.

Bordás Péter (2015): Határtalan hatások a pénzügyi decentralizációban - A forrásszabályozási rendszer értékelése településkategóriák alapján. Miskolci Jogi Szemle, X. évfolyam, 2015. 1. szám, 129-147.

Bordás Péter (2019): Miból vagy mire? Vízválasztó az önkormányzati finanszírozásban. Debreceni Egyetemi Kiadó, Debrecen.

EC (2010) European Commission: Flash Eurobarometer 277 - Perception survey on quality of life in European cities. http://data.europa.eu/euodp/en/data/dataset/S764_277_A_B_C_D

EC (2013) European Commission: Flash Eurobarometer 366 - Quality of Life in European Cities. https://ec.europa.eu/commfrontoffice/publicopinion/index.cfm/Survey/getSurveyDetail/ instruments/FLASH/surveyKy/1035

EC (2016) European Commission: Flash Eurobarometer 366 - Quality of Life in European Cities. https://ec.europa.eu/commfrontoffice/publicopinion/index.cfm/Survey/getSurveyDetail/ instruments/FLASH/surveyKy/2070

Eurostat (2018): Government revenue, expenditure and main aggregates 2009-2018, Elérhető: http://ec.europa.eu/eurostat/data/database

Fónai Mihály (2015): Empirikus szociológiai felmérések a területi közszolgáltatások témakörében In: Horváth M. Tamás (szerk.): Külön utak: közfeladatok megoldásai. Dialóg Campus Kiadó, Budapest, 307-329.

Gajduschek György (2012): Változások az önkormányzati rendszerben - egy értelmezési kísérlet. Fundamentum, No. 2, 61-73.

Horta, Xavier Bertrana-Fornes, Mariona Tomas (2015): Systems Of Local Government in Europe and their Chief Executive Officers. Institut de Ciències Polítiques i Socials. Diputació Barcelona.

Hoffman István (2016): Hely a társadalom hálózatában: szociális szolgáltatások. In: Horváth M.Bartha (szerk): Közszolgáltatások megszervezése és politikái. Merre tartanak? Budapest-Pécs, Dialóg Campus. 325-399. 
Horváth M. Tamás - Péteri Gábor - Vécsei Pál (2014): A helyi forrásszabályozási rendszer magyarországi példája, 1990-2012. Közgazdasági Szemle, LXI. évf., 2014. február, 121-147.

Horváth M. Tamás (2002): Helyi közszolgáltatások szervezése. Dialóg Campus, Budapest.

Horváth M. Tamás (2012): Kiszervezés - visszaszervezés: A helyi közszektor változása. Fundamentum, No. 2, 5-10.

Horváth M. Tamás-Bartha Ildikó (szerk.) (2016): Közszolgáltatások megszervezése és politikái. Merre tartanak? Budapest-Pécs, Dialóg Campus.

Horváth, M. Tamás-Péteri Gábor (2013): Nem folyik az többé vissza. Az állam szerepének átalakulása a víziközmú szolgáltatásban. In: Valentiny Pál-Kiss Ferenc László-Nagy Csongor István (szerk.): Verseny és Szabályozás. Budapest, MTA KRTK Közgazdaság-tudományi Intézet, 177-200.

Hydman, David N. (2011): Public Finance. A Contemporary Application of Theory to Policy. Tenth Edition, South-Western, Cengage Learning, Mason, USA.

Javaslat (2018): Javaslat a helyi közszolgáltatások finanszírozásának (normatíva) felülvizsgálatára KÖFOP2.3.3-VEKOP-16-2016-00001 azonositó jelü "Helyi versenyképesség-fejlesztési kutatási program” címú kiemelt projekt kapcsán. HBH Stratégia és Fejlesztés Kft. és Collective-Intelligence Kft. konzorcium, Budapest.

Kákai László-Vető Balázs (2019): Állam vagy/és önkormányzat? Adalékok az önkormányzati rendszer átalakításához. Politikatudományi Szemle, XXVIII/1. 17-41. https://doi.org/10.30718/POLTUD. HU.2019.1.17

KJ 1 (2018): 1 Célterület Összefoglaló Kutatási Jelentés: 1. célterület: A helyi közszolgáltatások minöségfejlesztése KÖFOP-2.3.3-VEKOP-16-2016-00001 azonositó jelü "Helyi versenyképesség-fejlesztési kutatási program" címü kiemelt projekt kapcsán. HBH Stratégia és Fejlesztés Kft. és CollectiveIntelligence Kft. konzorcium, Budapest.

KJ 2 (2018): 2 Célterület Összefoglaló Kutatási Jelentés: 2. célterület: A helyi közszolgáltatások feladatellátás-szervezési megoldásai, KÖFOP-2.3.3-VEKOP-16-2016-00001 azonosító jelü „Helyi versenyképesség-fejlesztési kutatási program" cimü kiemelt projekt kapcsán. HBH Stratégia és Fejlesztés Kft. és Collective-Intelligence Kft. konzorcium, Budapest.

Martinez-Vazquez, Jorge-Sepulveda, Cristian (2012): Toward a More General Theory of Revenue Assignment. International Center for Public Policy, Working Paper, Atlanta. https://doi.org/10.2139/ ssrn. 2188954

Musgrave, Richard A. (1959): The Theory of Public Finance. New York, McGraw Hill.

Oates, Wallace E. (1972): Fiscal federalism. New York, Harcourt Brace Jovanovich.

OECD (2016): Subnational Government Structure and Finance. Forrás: https://stats.oecd.org/index. aspx?queryid=72696

Pálné Kovács Ilona (szerk.) (2016): A magyar decentralizáció kudarca nyomában, Budapest-Pécs, Dialóg Campus.

Péteri, Gábor (2016): Decentralization in Eastern Europe: Grab the Moment! Public Goods $\mathcal{E}$ Governance, Vol. 1, Issue 2., 22-27. https://doi.org/10.21868/PGnG.2016.2.5.

Steffensen, Jesper (2010): Fiscal decentralization and sector funding principles and practices. Udenrigsministeriet Dania.

Tiebout, Ch.M. (1956): „A Pure Theory of Local Expenditures”. - The Journal of Political Economy. 5., 416-424. https://doi.org/10.1086/257839

Vági Gábor (1982): Versengés a fejlesztési forrásokért. Budapest, Közgazdasági és Jogi Könyvkiadó. 